The terms are neologisms and present little difficulty in translation. Why it is so? Because they are not yet reflected in the dictionaries. Especially many neologisms among brand names, that is, the names of certain products manufactured by the company.

A cliché occupies a special and special place in the technical texts. Clichés include idioms, persistent expressions, a set of ready phrases.

Also, one of the characteristic features of technical texts is the use of special technical phraseology.

Various abbreviations and abbreviations are widely used in modern scientific and technical literature. Please note that generally accepted abbreviations are official and cannot be modified or replaced.

Therefore, the main function of the technical literature is the message this determines the information function of the language of scientific and technical literature [1, p. 15].

\title{
References:
}

1. Kovalenko, A. (2003). General course of scientific and technical translation: A guide for translation from English. Kiev: «INCOS».

\section{VERBAL EXPRESSION OF FEMINITIVES IN CARMEN LAFORET'S NOVEL «NOTHING»}

\section{Karina Ibryshymova ${ }^{1}$ Liudmyla Shuppe ${ }^{2}$}

\section{DOI: https://doi.org/10.30525/978-9934-588-52-5-10}

The feminist research on the Iberian Peninsula began to develop actively in the 1970s after Franco's death, with modification of dicta dura (dictadura) in dicta blanda (bland dictate), because social and economic changes influenced traditional patriarchal consciousness of macho Spanish society and caused the reconsideration of the role of women in community [5]. Gender stereotypes reflect the national consciousness, demonstrating the characteristics of the people, their way of life and traditions. Characterizing masculinity and femininity, we find an explanation of the differences in the nature of both sexes (perhaps not always reliable), which is the result of collective experience and that is passed down from generation to generation.

${ }^{1}$ Odessa I.I. Mechnikov National University, Ukraine

${ }^{2}$ Odessa I.I. Mechnikov National University, Ukraine 
Gender stereotypes are actively used in daily routine, serving as ways of expression in literature and permit to explore certain features of the mentality of peoples in different parts of the world and in different historical epochs by the study of works of art. Carmen Laforet was the first who addressed this issue and made a significant contribution to gender studies.

In order to confirm the existence of gender stereotypes in Spain of this period, it becomes obvious to study the gender-specific characteristics of the speech of the characters. In her novel, Carmen Laforet skillfully demonstrates the communicative behavior of both sexes, as she was a member of society at that time, fluent in the language, personally observed gender stereotypes in speech and tried to reproduce them as much as possible.

In the novel «Nothing» gender stereotypes are transmitted through the verbal expression of the characters. The grammatical gender of the noun, of course, is not equal to gender in either Spanish or Ukrainian. However, due to traditional androcentrism, the recipient usually identifies the pronoun and the noun of the masculine gender with the male sex [5]. Analyzing the femininities in the work, including female pronouns and characteristic forms of female appeals, we can conclude that the number of sentences in which women appeared is much greater than those in which men did.

Compared with other Romance languages, the grammatical gender of the pronouns of the first and second person plural (nosotras / vosotras) is characteristic of the Spanish language. Many researchers, including Gorinova, tend to believe that this is the influence of the Arabic language [1, p. 88]. In the text the forms nosotras and vosotras are mentioned 8 and 3 times, when the collective notion nosotros -26 , vosotros -8 , respectively, which not only indicates only males, but also the presence of women and men and in the text once again proves the silence of women in language, because the number of women in the collective concept exceeds men.

However, the tendency to single out feminine pronouns, common nouns in relation to the female subject is sometimes excessive without any reason. According to the Spanish Academy, the separation of sex (señoras y señores, ciudadanos y ciudadanas, chicos y chicas, niños y niñas, voluntarios $\mathrm{y}$ voluntarias) is justified if there is a moment of opposition. The academy expressed its views on this issue in 2012, stating that «it would be impossible to say how the rigid version proposed in the guides of non-sexist Spanish (which do not exclude the possibility of depriving the male gender of traditional androcentric function) (masculino genérico) would be applied» [5].

In addition to the traditional forms of verbal expression of women (abuela, mujer, señora, señorita, chica, ella, tía), the text contains such as «mujerzuela» (2 mentions), which indicates a vicious woman who has strayed from the right path and repeatedly proves humiliation to the female sex, while the bad image 
of the character on the contrary is exaggerated by the word «señorón» as an important person. The image of grandmother in the Spanish context is often presented with the suffix of affection -ita (abuelita), which shows a respectful and loving attitude towards this person. There is also a noticeable appeal to women in the form of substantivized adjectives «bella (9)», «bonita» (10), which positively or ironically characterize a woman, and appear in the novel in the form of pyrops (unfriendly macho treatment of women, which is sometimes equated to the Ukrainian exclamation»Hey!» and is most often accompanied by a whistle). «Bonito» (6) is also used in relation to men, but in the work it is only exploited as a characteristic (not an address). Since there are no equivalents to the lexeme «bella» in the masculine adjectives, the contextual synonym «bueno» (13) is made use of, but also without the meaning of address, but only description.

The verbal expression of women includes a special role that is assigned to each heroine in the work. Therefore, the female series is represented by such roles as: woman (91 mentions, including woman as a wife), girlfriend (44), señora (married woman - 16), señorita (unmarried woman -12 ), grandmother (144), bride (1), niece (22), sister (30), aunt (30), mistress (7), beloved (12), maid (32), student (4), mother (62).

Thus, it becomes clear that the greatest place in the work is occupied by family ties, which shows the name of a particular family member. The grandmother is most frequently mentioned, although she is not the main character, which proves her authority and respect for her person. The address «querida» (beloved) in the text corresponds to the masculine «cariño», which is almost equal to each other, so both women and men equally use these lexemes to address their spouses.

The gender stereotype towards women is vividly represented by the feminine «bruja» (witch), which occurs 10 times in the context, which demonstrates the remnants of macho society and indicates the humiliation of women and the widespread belief that women have supernatural powers.

The novel «Nothing» also ridicules the limited intellectual capacity of the lexeme «estupidez», with $75 \%$ of women (3 mentions) and 25\% (1) of men, respectively. The address "picarona» (6 mentions) is also used with a similar meaning, which can be heard not only from men's lips, but can also be seen in addresses between women in person. This verbal expression is not justified, because women were educated on an equal level with men and also acquired low skills.

Women in the novel appear as verbally active individuals, because the text is more saturated with female lines than men. At the same time, there is a stereotype about the excessive talkativeness of a woman, who in the text is compared to a flock of crows: 
Another typical female trait is a change of mood, which is expressed in the context: «De pronto a mí me pareció todo aquello idiota, cómico y risible otra vez. $Y$ sin poderlo remediar empecé a reírme cuando nadie hablaba ni venía a cuento, y me atraganté. Me daban golpes en la espalda, y yo, encarnada y tosiendo hasta saltárseme las lágrimas, me reía; luego terminé llorando en serio, acongojada, triste y vacía» [2, p. 52]. The verbs «reirse», «llorar» in this quote emphasize the complete opposite of actions, which has no definite reasons, which once again indicates a gender stereotype.

Thus, the influence of the gender factor can be traced in verbal expression as well. The main features of the speech of female characters in the novel are an attentive attitude to the speaker, the predominance of general positive assessment, the use of stylistically colored vocabulary, the use of syntactic constructions that increase the emotional colouring of speech, etc. The speech behavior of male characters is characterized by the following features: the desire to achieve leadership and demonstrate a high level of erudition, focus on their own problems, unwillingness to take into account the interests of the interlocutor, general neutral or negative assessment, restraint and so forth.

\section{References:}

1. Gorinova, O. V. (2004). Nekotorye proyavleniya seksizma na grammaticheskom urovne (na materiale feministskikh issledovaniy $\mathrm{v}$ ispanskom yazyke) [Actualization of the Concept of Sexism on Grammatical Level (Basing on the Researches on Feminism in the Spanish Language]. Vestnik Rossiyskogo universiteta druzhby narodov. Seriya: Lingvistika, no. 6, pp. 87-91.

2. Laforet C. Nada. Le libros.

3. Petrova, A. V. (2018). Suchasni doslidzhennja ghenderologhiji: zistavlennja ponjatj «ghendernyj stereotyp» i «linghvokuljturnyj typazh» [Contemporary Researches on Genderology: Juxtaposition of Notions "Gender Stereotype» and «Linguocultural Type»]. Naukovyj visnyk DDPU imeni I. Franka. Serija «Filologhichni nauky». Movoznavstvo, no. 10, pp. 95-98.

4. Ryabova, T. B. (2003). Stereotipy i stereotipizatsiya kak problema gendernykh issledovaniy [Stereotypes and Stereotypization as an Obstacle in Gender Researches]. Lichnost'. Kul'tura. Obshchestvo, vol. 5, no. 1-2 (15-16), pp. 120-139.

5. Zhorzh, T. K. (2018). Feminitiv: lingvisticheskiy aspekt i problema perevoda [The Feminitives: Linguistic Aspect and Translation Difficulties]. Prepodavatel' XXI vek [A Teacher of XXI century] (electronic journal). Retrieved from: https://cyberleninka.ru/article/n/feminitiv-lingvisticheskiy-aspekt-i-problema-perevoda (accessed 12 May 2020). 